\title{
Oncology Nursing and EONS (European Oncology Nursing Society) influence in Eastern Europe
}

\author{
Silvija Piškorjanac
}

University Hospital Osijek, Croatia

Faculty of Dental Medicine and Health, University J. J. Strossmayer Osijek, Croatia

Silvija Piškorjanac, RN, MNs, CNS, PhD Candidate

University Hospital Osijek, Croatia

Faculty of Dental Medicine and Health, University J. J. Strossmayer

Osijek, Croatia

Lecturer at the Department of Palliative Care and Nursing

e-mail: spiskorjanac@fdmz.hr
Proces prihvatanja/Article history:

Primljeno/Received 9.04.2021

Revidirano/ Received in revised form 18.04.2021.

Prihvaćeno/ Accepted 19.04.2021.

\section{ONKOLOŠKO SESTRINSTVO I EONS (EVROPSKO ONKOLOŠKO SESTRINSKO DRUŠTVO) UTICAJ U ISTOČNOJ EVROPI}

\section{SAŽETAK}

Evropska unija (EU) definisala je proces i norme obrazovanja medicinskih sestara/tehničara. Kao izvor podataka korišćena je Direktiva 2005/36/ EC i Direktiva 2013/55/ EU zajedno s hrvatskim zakonima i propisima koji se odnose na obrazovanje medicinskih sestara/tehničara. Obrazovanje medicinskih sestara/ tehničara u Republici Hrvatskoj sprovodi se kroz srednjoškolsko obrazovanje, kao i na akademskom nivou. Slična je ili ista situacija u mnogim istočnoevropskim zemljama. Iskustvo u obrazovanju medicinskih sestara/tehničara u različitim evropskim i ostalim zemljama sveta može biti korisno za poboljšanje obrazovanja medicinskih sestara/tehničara u Republici Hrvatskoj.

Specijalizacija za medicinske sestre/tehničare iz onkološko hematološke delatnosti u Republici Hrvatskoj, kao i u mnogim istočnoevropskim zemljama, postoji samo na papiru, za razliku od zemalja zapadne Evrope, SAD-a ili Australije. Istočnoevropske onkološke medicinske sestre/tehničari se mogu usavršavati uz pomoć EONS-a (Evropskog onkološkog društva medicinskih sestara/tehničara) kao krovne organizacije koja je lider u svim područjima zdravstvene nege onkoloških bolesnika, istraživanja, prakse, kontinuirane edukacije, komunikacije i pregovaranja radi boljeg prepoznavanja onkološke zdravstvene nege širom Evrope. Ključne reči: edukacija, sestrinstvo, onkologija, zdravstvena nega

\begin{abstract}
European Union (EU) has defined the process and norms of nursing education. As a source of data, Directive 2005/36/EC and Directive 2013/55/EU was used together with Croatian laws and regulations which are related to nursing education. Nursing education in Croatia is carried out through high school education and also at the university level. The situation is similar or the same in many other Eastern European countries. Experience in nursing education in different European countries can be useful in improving nursing education in Croatia.

Cancer nursing specialization in the Republic of Croatia, as in many Eastern European countries, exists only on paper, unlike in Western Europe, the USA or Australia. Eastern European cancer nurses can be trained with the assistance of EONS (European Oncology Nursing Society) which is an umbrella organisation providing leadership in all areas of cancer nursing, research, practice, continuing education, communications and advocacy for better recognition of cancer nursing across Europe.
\end{abstract}

Key words: education, nursing, cancer nurses, oncology 


\section{INTRODUCTION}

Nursing education is a permanent process that serves for personal and professional development [1]. Nursing education in Croatia has a long tradition, and since the beginnings of education in 1921 till these days it has gone through many changes. Today nursing education is based on the World health organization's Strategy for nursing and midwifery education and recommendations of European Council Directive 2005/36 on the recognition of professional qualifications. Education is regulated by The Act on Scientific Activity and Higher Education and principles of the Bologna process is applied [2].

Unfortunately, these strategies still do not regulate the issue of specializations in the nursing profession.

\section{DISCUSSION}

The present status of nursing education in Croatia is a controversial matter. Croatia is the only country that trains general care nurses at the level of five-year secondary vocational education. It is also the only form of secondary education in Croatia that lasts five years with a program of 4600 hours in three years of secondary vocational school for nurses and the previous two years of general education. In the Republic of Croatia, only secondary schools for nurses have a 10-year basic education: 2 years of general education +3 years of vocational education [3] Significant changes occurred in 2005 with changes of The Act on Scientific Activity and Higher Education and application of principles of the Bologna process which enabled education in nursing in two cycles. By finishing the first cycle of nursing study students gather 180 European Credit Transfer and Accumulation System (ECTS) credits and become a bachelor of nursing. The education at first cycle with a uniform curriculum is provided in four educational institutions in Croatia, whereby efforts are made to establish more institutions for nursing education. Every year about 300 students enroll in nursing studies. After finishing the first cycle, the nurse can continue studying nursing on master studies/nursing specialisations and gather another 120 ECTS credits. There are two nursing specialisations in Croatia at the moment: Management in Nursing and Public Health [3].

Upon completion of the university graduate study, participants acquire 120 ECTS credits and the title of master of nursing, which allows them to continue their education in one of the doctoral studies. For the time being, the enrollment of the doctoral study is enabled at the medical faculties or other faculties within the University [3].

Therefore in Croatia, there is a five-year vocational education as a basic nurse education, then undergraduate professional and university nursing studies, after that a graduate professional and university studies in nursing, and finally doctoral studies in biomedical sciences, thus reaching a total number of 14 different terminologies for nurses. On the one hand, forms of education are provided at different levels (undergraduate, graduate, professional and university nursing studies), but on the other hand, the health system does not recognize and valorize nurses as experts. Regardless of education, the largest number of highly educated nurses receive a bachelor's salary. There are exceptions that depend on the workplace and the institution of employment (management position, nurse educators, etc).

Considering specializations in nursing in the Republic of Croatia, the situation is the same or similar as in most other Eastern European countries. Cancer nursing specialization, like other nursing specialization, exists only on paper, unlike in Western Europe, the USA or Australia.

Historically, nurses have had a special role in the care of patients with cancer. However, the expanded research and treatment program against cancer that has occurred during the past quarter-century has been a catalyst for the development of oncology nursing as a separate specialization [4].

The recognition of cancer as a major national health problem was a key for formally establishing the specialization of oncology nursing in the USA, Australia and most Western European countries. This increased attention to cancer coincided with and complemented a major new emphasis in the nursing profession toward expanded roles in comprehensive patient care. Many oncology nurses first worked as both nurses and data managers for cancer research studies. As oncology called for increasingly more complex therapy, the collaborative relationship between nurse and physician became the best way to provide uniquely comprehensive patient care $[5,8]$.

The roles of the oncology nurses vary from the intensive care focus of bone marrow transplantation to the community focus of cancer screening, detection, and prevention $[6,8]$. As the healthcare delivery system changes and new scientific discoveries are integrated into cancer care, the role of the oncology nurse will continue to evolve. Oncology nurses currently work in a variety of roles and settings that were unheard of 
10 years ago but are nowadays increasingly common. In the ambulatory setting, oncology nurses function in nurse-run clinics that provide services such as long-term follow-up care to patients with cancer, prescreening prior to chemotherapy administration, the management of fatigue, or general symptom management. As the field of cancer genetics has developed, so have the roles for advanced practice nurses in the provision of cancer genetic counselling and risk assessment $[7,8]$.

Considering the above examples, it seems that nursing specializations in Croatia are still undeveloped comparing to the rest of the world. However, as a source of further development of nursing specializations, EONS (European Oncology Nursing Society) can be helpful.

What is EONS? Why is so important for cancer nursing and cancer nurses in Eastern Europe? European Oncology Nursing Society (EONS) is an umbrella organisation providing leadership in all areas of cancer nursing, research, practice, continuing education, communications and advocacy for better recognition of cancer nursing across Europe which lead to better patient care. In Croatia, there is a national society called Croatian Oncology and Hematology Nursing Society which is a member of EONS since 2003. There are $300-400$ cancer nurses in Croatia but not all of them are members of the national society.

There is a number of examples that point to the role that EONS plays in oncology nursing, whether in a clinical setting or nursing education. One of them is the EONS Cancer Nursing Framework which is the basis of the cancer care curriculum for nursing students at some medical faculties in Croatia. It would be useful if it was applicable at the national level. The other example is EONS Euro PEPs (Putting Evidence into Practice) guidelines. They are designed to help nurses to improve their use of research evidence in their clinical practice. There are Euro PEPs on Dyspnea, Lymphoedema, Pain, Peripheral neuropathy and Radiodermatitis, in five European languages among which is the Croatian language. Clinical practice guidelines for „Management of chemotherapy extravasation", which are the product of cooperation between the European Society for Medical Oncology (ESMO) and EONS, are currently in the process of translating to the Croatian language. „Breakthrough cancer pain guidelines" and "Cancer Therapy - Induced Nausea \& Vomiting in Adults" are also in the process of translating to Croatian.
Croatian national society also applied for financial support to translate „Target" materials which will be used for the course during the regular national annual meeting. "Target" course is one of the best possible courses to understand this dynamically growing treatment area and will give nurses the knowledge to improve care and support for patients and their caregivers. More precisely, „Target" give nurses a better understanding of the characteristics associated with cancer development and how targeted therapies have improved patient outcomes by inhibiting or manipulating these oncogenic characteristics [9].

The Masterclass in Oncology Nursing is specifically designed to meet the educational needs of cancer nurses from Eastern Europe and the Balcan region. The 1st Masterclass was held in Budapest 2018. Due to the ongoing COVID-19 pandemic, the EEBR 2020 Masterclass faculty has decided to postpone this event, which was scheduled to take place in November 2020 in Belgrade, to a later date in 2021. The Masterclass learning objectives are to understand new developments in cancer disease management, to recognize and describe acute and late adverse effects of cancer and its treatment, to identify complex patient needs across the cancer trajectory and to describe the role of the advanced oncology nurse in leading clinical nursing care [10]. An ideal candidate for this Masterclass would be a nurse with 5-10 years of experience in cancer nursing.

And finally, the young cancer nurses should be mentioned. In Croatia, there is a group of young, smart and capable nurses. They are ambitious, eager for knowledge, full of ideas. They are very active in social media and at the same time very active member of the EONS Young Cancer Nurses (YCN) Network. For example, in the EONS' latest project "EONS Young Cancer Nurses Nightingale Challenge Webinar Series", YCN Croatia actively participated.

\section{CONCLUSION}

Nursing is a dynamic discipline characterised by the need for quality basic nursing education which is necessary for safe and quality nursing care and the basis for nursing specializations. A life long learning is characteristic of nursing and an obligation for nurses, due to the everyday fast advance in medical sciences and nursing. In order to become as good as possible in the nursing profession, all the available help should be used. Considering cancer nursing, that help is definitely EONS (European Oncology Nursing Society) and all its resources. 


\section{REFERENCES:}

1. Nursing and Midwifery. World Health Organization: Geneva, Switzerland, 2020. Available online: http://www.who.int/ topics/nursing/en/ (accessed on 12 November 2020).

2. Direktiva 2005/36/EZ Europskog parlamenta i Veća od 7. rujna 2005. o priznavanju stručnih kvalifikacija. Publications Office of the European Union, 2020. Available online: https://eur-lex.europa.eu/legal-content/HR/TXT/?uri=celex\%3A32005L0036 (accessed on 12 November 2020).

3. Zakon o Hrvatskom kvalifikacijskom okviru. Ministarstvo znanosti, obrazovanja i sporta. Agencija za znanost i visoko obrazovanje: Zagreb, 2013. Available online: https://www.azvo.hr/images/stories/novosti/Zakon_o_HKO-u.pdf/ (accessed on 12 November 2020).

4. Yarbro CH. The history of cancer nursing. In: McCorkle R, Grant M, Frank-Stromborg M, Baird SB, editors. Cancer nursing, 2nd ed. Philadelphia: WB Saunders; 1996. p. 12-24.

5. Mayer DK, editor. Celebrating our past, creating our future. Oncol Nurs Forum. 2000;28:Supplement.

6. Oncology Nursing Society. Demographics report, as of October 1, 2002. Pittsburgh, PA: Oncology Nursing Society; 2002.

7. Greco KE. Cancer genetics nursing: impact of the double helix. Oncol Nurs Forum. 2000;27(9):29-36.

8. Kufe DW, Pollock RE, Weichselbaum RR, Bast RC, Gansler TS, Holland JF, et al., editors Holland-Frei Cancer Medicine. 6th edition. Hamilton (ON): BC Decker; 2003.

9. Hanahan D, Weinberg RA. Hallmarks of cancer: the next generation. Cell. 2011;144(5):646-674.

10. About EONS. European Oncology Nursing Society: Brussels, Belgium, 2020. Available online: https://cancernurse. eu/about-eons/ (accessed on 12 November 2020). 